\title{
Polymorphism C242T in the Cyp19 gene in meat sheep
}

\author{
N. H. A. P. Mora ${ }^{a}$, S. C. C. Silva ${ }^{a}$, F. Tanamati ${ }^{a}$, G. P. Schuroff, F. A. F. Macedo ${ }^{c}$ and \\ E. Gasparino \\ aPrograma de Pós-graduação em Zootecnia, Universidade Estadual de Maringá - UEM, Av. Colombo, 5790, \\ CEP 87020-900, Maringá, PR, Brazil \\ bUniversidade Estadual de Maringá - UEM, Av. Colombo, 5790, CEP 87020-900, Maringá, PR, Brazil \\ 'Departamento de Zootecnia, Universidade Estadual de Maringá - UEM, Av. Colombo, 5790, \\ CEP 87020-900, Maringá, PR, Brazil \\ *e-mail: natalia-mora@hotmail.com
}

Received: August 21, 2014 - Accepted: November 21, 2014 - Distributed: February 29, 2016 (With 1 figure)

\begin{abstract}
The objective of this study was to evaluate the frequency of C242T polymorphism on the aromatase gene and the allelic and genotypic frequency of these variants in sheep belonging to four breed groups. Blood samples were collected from 187 animals of four breed groups: Dorper, Santa Inês, Texel and White Dorper, originated from herds in the region of Maringá/PR, Brazil. The genomic DNA was extracted using alkaline extraction, with subsequent amplification of the fragments via PCR with specific primer. The samples resulting from amplification were subjected to digestion process using the $D p n$ II restriction enzyme and to polyacrylamide gel electrophoresis $10.0 \%$ and stained with silver nitrate. Three distinct genotypes were observed: homozygous (CC), heterozygous (CT) and homozygous for no cut (TT). The resulting data were analyzed using the POPGENE software with 5\% significance. Genotypic frequencies among the breed groups were: Texel (CC - 0.426; CT - 0.511; TT - 0.064), Dorper (CC - 0.073; CT - 0.732; TT - 0.439), White Dorper (CC - 0.021; CT - 0.255; TT - 0.723) and Santa Inês (CC - 0.115; CT - 0.462; TT - 0.423).
\end{abstract}

Keywords: Cyp19, Dorper, polymorphism, Santa Inês, Texel, White Dorper.

\section{Polimorfismo no gene cyp19 em ovinos de corte}

\section{Resumo}

O objetivo deste trabalho foi avaliar as frequências alélicas e genotípicas do polimorfismo do C242T no gene da aromatase em ovinos pertencentes a quatro grupos raciais. Foram coletadas amostras de sangue de 187 animais de quatro grupos raciais: Dorper, Santa Inês, Texel e White Dorper, provenientes de rebanhos da região de Maringá, PR - BR. O DNA genômico foi extraído utilizando o método de extração alcalina, com posterior amplificação dos fragmentos via PCR com primer específico. As amostras resultantes da amplificação foram submetidas ao processo de digestão com auxilio da enzima restrição $D p n$ II e submetido à eletroforese em gel de poliacrilamida de $10,0 \%$ e corado nitrato de prata. Foram observados três genótipos distintos: Homozigoto (CC), heterozigoto (CT) e homozigoto para não corte (TT). Os dados resultantes foram analisados utilizando o software POPGENE com significância de $5 \%$. As frequências genotípicas entre os grupos raciais foram: Texel (CC - 0,426; CT - 0,511; TT - 0,064), Dorper (CC - 0,073; CT - 0,732; TT - 0,439), White Dorper (CC - 0,021; CT - 0,255; TT - 0,723) e Santa Inês (CC - 0,115; CT - 0,462; TT - 0,423).

Palavras-chave: Cyp19, Dorper, polimorfismo, Santa Inês, Texel, White Dorper.

\section{Introduction}

Estrogen is an endocrine hormone involved in the regulation of reproductive and productive traits such as fat deposition (Heine et al., 2000; Jones et al., 2000) and body growth (Simpson et al., 2000). The biosynthesis of estrogen is performed by the aromatase enzyme by the process of conversion or aromatization of androgens (C19) to estrogens (C18). The aromatase enzyme is dependent on cytochrome P450 and is coded by the Cyp19 gene. It is expressed in several tissues, including granulosa and luteal cells of the ovary, Sertoli and Leydig cells of the testicles, brain, adipocytes, liver, muscle, hair follicles and bone (Damiani and Damiani, 2007).

Aromatase is directly linked to folliculogenesis, affecting oocyte quality. Furthermore, this enzyme can also be related to the stimulation of estrus and development of the mammary glands. In humans, polymorphisms in the aromatase gene have been associated with risk of development of estrogen-responsive tumors (Fernando, 2010), higher 
levels of estrogen early puberty (Lee et al., 2014) and lower bone mineral density (Markatseli et al., 2014). Also in humans, studies have found that some polymorphisms in the Cyp19 gene may have effects on the prognosis of breast cancer (Zins et al., 2014).

In sheep, the Cyp19 gene that codes the aromatase enzyme is located in chromosome 7 (Payen et al., 1995), has a length of $1,546 \mathrm{bp}$, with an open reading frame of $1,509 \mathrm{bp}$. It is transcribed by four different promoter regions that have organ-specific activities. The $\mathrm{P} 2$ promoter region is mostly active in granulosa cells; P1.5 and P1.1, in the placenta; and P1.4 is active in the brain (Vanselow et al., 1999, 2001). The translation of the mRNA may generate a protein with 503 amino acids.

In studies on the Cyp19 gene in sheep, Vanselow et al. (1999) found a silent-transition (C/T) polymorphism located at codon 69 of exon 3 . This transition is seemingly related to a greater live weight at slaughter (Tanamati et al., 2013a) and larger loin-eye area (Tanamati et al., 2013b). In addition, this polymorphism seems to cause differences in other performance traits in sheep, influencing reproductive aspects and maternal ability, and is apparently related to different breed groups (Lôbo et al., 2009).

These studies demonstrated the importance of research on genetic characterization for the aromatase gene in distinct populations. Thus, the objective of this study was to evaluate the allelic and genotypic frequencies of the aromatase gene and compare them in four racial groups of sheep in Brazil.

\section{Material and Methods}

Blood samples were collected from 187 animals of four economically relevant breed groups in sheep-meat production: Dorper $(n=41)$, Santa Inês $(n=52)$, Texel $(n=47)$ and White Dorper $(n=47)$, originated from herds in the region of Maringá/PR, Brazil. The blood was collected in anticoagulant-containing tubes and stored for subsequent DNA extraction in the Laboratory of Molecular Biology at the Department of Animal Science of Universidade Estadual de Maringá.

Alkaline extraction was used to extract the DNA. Blood aliquots of $5 \mu \mathrm{L}$ were transferred to $1.5 \mathrm{~mL}$ tubes, then $25 \mu \mathrm{L} \mathrm{NaOH}$ were added and it was incubated in a water bath at $74^{\circ} \mathrm{C}$ for $10 \mathrm{~min}$. For the neutralization step, $25 \mu \mathrm{L}$ Tris- $\mathrm{HCl} \mathrm{pH} 8.0$ were added, and then the samples were used in the PCR reactions.

The PCR-RFLP (restriction fragment length polymorphism) technique was used to check the presence of polymorphism C242T in the aromatase gene. Primers obtained from Vanselow et al. (1999) were used for the amplification of the gene region, according to the sequence deposited on GenBank (AJ012153): primer 1 - 5'- CCA GCT ACT TTC TGG GCC TT- 3'; and primer 2-5' - CCT CCG GGT TTC CTC TCC ACA- 3'. The amplification reaction via PCR was performed on an Applied Biosystems or Techne TC-412 thermal cycler (Barloworld Scientific US, Burlington), using a reaction with a final volume of $15 \mu \mathrm{L}$. The amplification program consisted of initial desaturation at $94^{\circ} \mathrm{C}$ for 2 min, followed by 35 denaturation cycles at $94{ }^{\circ} \mathrm{C}$ for $15 \mathrm{~s}$, girdling at $55^{\circ} \mathrm{C}$ for $30 \mathrm{~s}$ and extension at $72^{\circ} \mathrm{C}$ for $2 \mathrm{~min}$, followed by a final extension at $72{ }^{\circ} \mathrm{C}$ for $5 \mathrm{~min}$.

The PCR product was subjected to digestion with Dpn II restriction enzyme (Biolabs ${ }^{\circledR}$, New England) on a thermal cycler. The reaction was performed with $10 \mu \mathrm{l}$ of PCR product, $5 \mathrm{U}$ of the Dpn II restriction endonuclease, $2.0 \mu \mathrm{l}$ buffer and $7.5 \mu \mathrm{l}$ pure water, in a final volume of $20 \mu \mathrm{l}$. The reaction was incubated for $8 \mathrm{~h}$ at $37^{\circ} \mathrm{C}$, followed by inactivation of $65^{\circ} \mathrm{C}$ for $20 \mathrm{~min}$.

The product of digestion was subjected to denaturing (6M urea) polyacrylamide gel electrophoresis $10 \%$ (acrylamide-bisacrylamide - 29:1) performed in a $1 \mathrm{X} \mathrm{TBE}$ buffer ( $90 \mathrm{mM}$ Tris-Borate and $2 \mathrm{mM}$ EDTA) at $180 \mathrm{~V}$ for four hours and stained with silver nitrate. After visualization of the bands, the gels were photographed with a digital camera (Nikon Coolpix S520). The individuals were genotyped by calculating the size of the alleles with 100-base-pair DNA ladder (Invitrogen). The fragments were identified and then the genotypic and allelic frequencies were determined at a 5\% significance level using the POPGENE 1.31 software (Yeh et al., 1999).

\section{Results}

Two alleles, "C" and "T", were observed in all analyzed populations; allele T, was an undigested PCR product with $140 \mathrm{pb}$ length, while allele $\mathrm{C}$ was a digested PCR product containing two fragments of 82 and $58 \mathrm{pb}$, respectively. Three distinct genotypes were observed based on the two alleles found: CC, CT and TT. As illustrated in Figure 1, CC is homozygous with complete digestion of the fragments, $\mathrm{CT}$ is heterozygous with cleavage in one allele, and TT is homozygous without digestion of the fragment.

The allelic and genotypic frequencies were statistically different among the breed groups (Table 1).

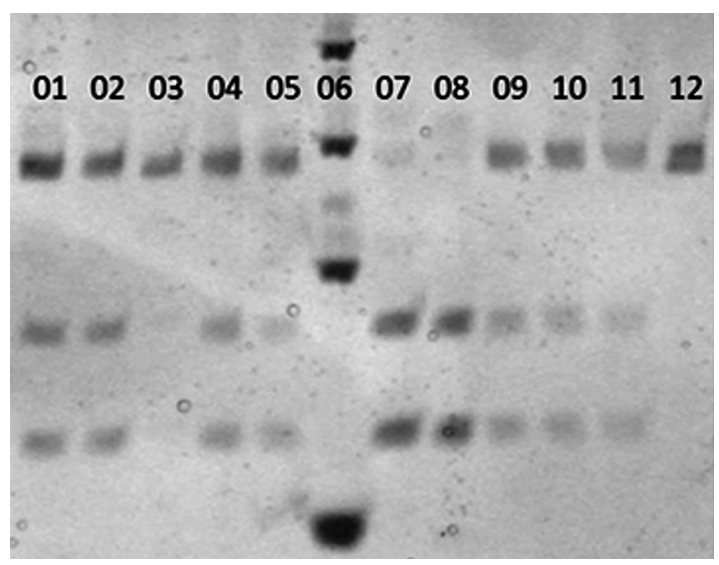

Figure 1. Analysis of the RFLP polymorphism of the aromatase (Cyp19) gene in sheep. Lane $06-100$ pb Ladder. Lanes 07 and 08 - animals with CC genotype (82 and $58 \mathrm{pb}$, respectively). Lanes 01, 02, 04, 05, 09, 10 and 11 - animals with CT genotype (82, 58 and $140 \mathrm{pb})$. Lanes 03 and 12 - animals with TT genotype (140 pb). Polyacrylamide Gel $10 \%$ 
Table 1. Allelic and genotypic frequencies of the breeds studied.

\begin{tabular}{lcccc}
\hline *Genetic group & T & D & WD & SI \\
\hline Animals (n) & 47 & 41 & 47 & 52 \\
\cline { 2 - 5 } & \multicolumn{5}{c}{ Frequencies of aleles } \\
\cline { 2 - 5 } Allele C & 0.681 & 0.317 & 0.149 & 0.346 \\
Allele T & 0.319 & 0.683 & 0.851 & 0.654 \\
\cline { 2 - 5 } & \multicolumn{5}{c}{ Frequencies of genotypes } \\
\cline { 2 - 5 } Genotype CC & 0.426 & 0.073 & 0.021 & 0.115 \\
Genotype CT & 0.511 & 0.732 & 0.255 & 0.462 \\
Genotype TT & 0.064 & 0.439 & 0.723 & 0.423 \\
\hline
\end{tabular}

$* \mathrm{~T}=$ Texel, $\mathrm{D}=$ Dorper, $\mathrm{WD}=$ White Dorper and SI = Santa Inês.

\section{Discussion}

The geographic origin of the animals and the latitude where they are located are important factors regarding the sheep reproductive activity, as these factors determine the photoperiods (Sá and Sá, 2006). Photoperiod acts according to retinal photoreceptors, retinohypothalamic tract, the suprachiasmatic nucleus, superior cervical ganglion nerves, such as the pineal gland and melatonin. Melatonin is an indoleamine derived from the serotonin secreted during darkness that acts as a natural inhibitor of the aromatases (Hafez and Hafez, 2003). Thus, the aromatase activity is closely related to the location and photoperiod in which animals are, with the intermediary activity of melatonin, its natural inhibitor.

The photoperiod guides the polyestrous seasonality of sheep in temperate regions, such that the estrus activity starts with the period when the light length is reduced and their offspring are born in the spring season (Jainudeen et al., 2003). For sheep located in tropical regions, however, the polyestrous seasonality is not evident, because the luminous intensity is constant. Females may show signs of estrum over the year, reducing the calving intervals, as observed in the Dorper, White Dorper and Santa Inês breed groups, originally from the Southern Hemisphere; this allows for production of a higher number of lambs.

A greater frequency of allele $\mathrm{T}$ was observed in the Dorper, White Dorper and Santa Inês breed groups, corroborating results found by Lôbo et al. (2009) in populations composed of $1 / 2$ Dorper $(n=18)$, Santa Inês $(n=71)$ and Somalis Brasileira $(n=13)$ animals. For the Texel breed group, however, allele $\mathrm{C}$ was observed at the highest frequency, disagreeing with the reports of Lôbo (2008), who evaluated the frequency of this polymorphism for $1 / 2$ Texel sheep and observed a greater frequency for allele $\mathrm{T}(0.670)$. However, the differences observed by these authors may result from the small number of analyzed animals ( $\mathrm{n}=3$ ) and/or because they were half-blood.

Data on C242T polymorphism of the aromatase gene (Cyp19) in pure sheep belonging to this breed group have not been described in Brazilian literature. Unlike the other evaluated breed groups, Texel sheep, originated from
Northern Netherlands, in the European continent, have a seasonal polyestrus behavior in females, and presence of wool. These factors may be related to the higher frequency of allele $\mathrm{C}$.

Vanselow et al. (1999) evaluated several breed groups of European sheep and estimated the frequencies for alleles $\mathrm{C}$ and $\mathrm{T}$, and allele $\mathrm{C}$ was the most common. The frequency observed for Hungarian Merino sheep was 0.74 allele $\mathrm{C}(\mathrm{n}=38)$, which was similar for breed groups: Awassi, Tsigaja, Brith Milk Sheep (0.6 allele C; $n=5)$, and Lacaune ( 1.0 allele $\mathrm{C} ; \mathrm{n}=5$ ).

In our study, the highest genotypic frequency found for the Texel breed group was 0.511 ( 24 animals), for the CT genotype. This breed group also showed a high frequency for the CC genotype (0.426), and for the other breed groups evaluated this genotype was found at a low frequency (Table 1). Vanselow et al. (1999) also found allele $\mathrm{C}$ in evaluated European sheep, but there are no literature data on genotypic frequency for the $\mathrm{CC}$ genotype in sheep. This genotype was not found by Lôbo et al. (2009) in several genetic groups evaluated.

Different genotypes for the aromatase gene may have an influence on some productive traits (first-calving index, weight at birth and at weaning, and daily weight gain) (Lôbo, 2008).

Although sheep have been reared in Brazil for decades and participate in genetic breeding programs, these animals still have reproductive patterns characteristic of their genealogy. In this study the greatest frequencies of allele $\mathrm{C}$ were found in the Texel group, which has European origin, from temperate climates, showing clear seasonal reproductive traits. The highest frequencies of allele $\mathrm{T}$, in turn, were found in sheep originated from tropical countries, having annual polyestrus and characteristics of a more constant estrus.

\section{Conclusion}

The presence of the CC genotype for the Cyp19 is being reported for the first time in Brazil in sheep. There are differences in the allelic and genotypic frequencies of the polymorphism in the aromatase gene (Cyp19) in sheep of the Dorper, Santa Inês, Texel and White Dorper breed groups. The data observed suggest a relationship between the higher incidence of alleles $\mathrm{C}$ and $\mathrm{T}$ with the ancestral geographic origin of the sheep.

\section{References}

DAMIANI, D. and DAMIANI, D., 2007. Manejo farmacológico da baixa estatura: o papel dos inibidores da aromatase: revisão. Jornal de Pediatria, vol. 83, no. 5, pp. 172-177. http://dx.doi. org/10.1590/S0021-75572007000700008.

FERNANDO, R.M.R.S.C., 2010. Polimorfismos do gene CYP19: associação com cancro da mama e com concentrações séricas de hormonas sexuais em mulheres pós-menopáusicas. Coimbra: Faculdade de Medicina, Universidade de Coimbra, 66 p. Masters Dissertation. 
HAFEZ, B. and HAFEZ, E.S.E., 2003. Ciclos reprodutivos. In: H. WAHID and E.S.E. HAFEZ. Reprodução animal. 7th ed. São Paulo: Manole, pp. 55-67.

HEINE, P.A., TAYLOR, J.A., IWAMOTO, G.A., LUBAHN, D.B. and COOKE, P.S., 2000. Increased adipose tissue in male and female estrogen receptor-alpha knockout mice. Proceedings of the National Academy of Sciences of the United States of America, vol. 97, no. 23, pp. 12729-12734. http://dx.doi.org/10.1073/ pnas.97.23.12729. PMid:11070086.

JAINUDEEN, M.R., WAHID, H. and HAFEZ, E.S.E., 2003. Ovinos e caprinos. In: H. WAHID and E.S.E. HAFEZ. Reprodução animal. 7th ed. São Paulo: Manole, pp. 173-182.

JONES, M.E., THORBURN, A.W., BRITT, K.L., HEWITT, K.N., WREFORD, N.G., PROIETTO, J., OZ, O.K., LEURY, B.J., ROBERTSON, K.M., YAO, S. and SIMPSON, E.R., 2000. Aromatase-deficient (ArKO) mice have a phenotype of increased adiposity. Proceedings of the National Academy of Sciences of the United States of America, vol. 97, no. 23, pp. 12735-12740. http://dx.doi.org/10.1073/pnas.97.23.12735. PMid:11070087.

LEE, H.S., KIM, K.H. and HWANG, J.S., 2014. Association of aromatase (TTTA) repeat polymorphisms with central precocious puberty in girls. Horumon To Rinsho, vol. 81, no. 3, pp. 395-400. PMid:24612204.

LÔBO, A.M.O., 2008. Estudo genético de características de importância econômica em uma população multirracial de ovinos de corte: uma abordagem quantitativa e molecular. Fortaleza: Universidade Federal do Ceará, 96 p. Masters Dissertation.

LÔBO, A.M.O., LÔBO, R.N. and PAIVA, S.R., 2009. Aromatase gene and its effects on growth, reproductive and maternal ability traits in a multibreed sheep population from Brazil. Genetics and Molecular Biology, vol. 32, no. 3, pp. 484-490. http://dx.doi. org/10.1590/S1415-47572009005000054. PMid:21637510.

MARKATSELI, A.E., LAZAROS, L., MARKOULA, S., KOSTOULAS, H., SAKALOGLOU, P., TIGAS, S., GEORGIOU, I. and TSATSOULIS, A., 2014. Association of the (TTTA)n repeat polymorphism of CYP19 gene with bone mineral density in Greek peri- and postmenopausal women. Horumon To Rinsho, vol. 81, no. 1, pp. 38-44. PMid:24621381.

PAYEN, E., SAIDI-MEHTAR, N., PAILHOUX, E. and COTINOT, C., 1995. Sheep gene mapping: Assignment of ALDOB, CYP19, WT and SOX2 by somatic cell hybrid analysis. Animal Genetics, vol. 26, no. 5, pp. 331-333. http://dx.doi.org/10.1111/j.1365-2052.1995. tb02668.x. PMid:7486251.
SÁ, C.O. and SÁ, J.L., 2006 [viewed 13 May 2014]. Estacionalidade reprodutiva em ovinos [online]. Piracicaba. Available from: http://www.farmpoint.com.br/radares-tecnicos/reproducao/ estacionalidade-reprodutiva-em-ovinos-155n.aspx

SIMPSON, E., RUBIN, G., CLYNE, C., ROBERTSON, K., O'DONNELL, L., JONES, M. and DAVIS, S., 2000. The Role of Local Estrogen Biosynthesis in males and females. Trends in Endocrinology and Metabolism, vol. 11, no. 5, pp. 184-188. http:// dx.doi.org/10.1016/S1043-2760(00)00254-X. PMid:10856920.

TANAMATI, F., SILVA, S.C.C., MORA, N.H.A.P., SCHUROFF, G.P., MACEDO, F.A.F. and GASPARINO, E., 2013a [viewed 13 May 2014]. Efeito do polimorfismo no gene da aromatase sobre a característica peso vivo ao abate em ovinos Santa Inês. In: Anais do X Simpósio Brasileiro de Melhoramento Animal [online], Uberaba, MG. Available from: http://sbmaonline.org. br/anais/x/trabalhos/pdf/6NKA.pdf

TANAMATI, F., SILVA, S.C.C., MORA, N.H.A.P., PEREIRA, H.L., MACEDO, F.A.F. and GASPARINO, E., 2013b [viewed 13 May 2014]. Efeito do polimorfismo no gene da aromatase sobre a característica peso vivo ao abate em ovinos Santa Inês. In: Anais do X Simpósio Brasileiro de Melhoramento Animal [online], Uberaba, MG. Available from: http://sbmaonline.org. br/anais/x/trabalhos/pdf/6NK4.pdf

VANSELOW, J., FÜRBASS, R., ZSOLNAI, A., KALBE, C., SAID, H.M. and SCHWERIN, M., 2001. Expression of the aromatase cytochrome P450 encoding gene in cattle and sheep. The Journal of Steroid Biochemistry and Molecular Biology, vol. 79, no. 1-5, pp. 279-288. http://dx.doi.org/10.1016/S09600760(01)00144-3. PMid:11850234.

VANSELOW, J., ZSOLNAI, A., FESUS, L., SCHMIDT, P. and SCHWERIN, M., 1999. Bsp143I PCR-RFLP in exon 3 of the ovine aromatase gene (CYP19). Animal Genetics, vol. 30, no. 5, pp. 402-405. http://dx.doi.org/10.1046/j.1365-2052.1999.0052625.x. PMid: 10582308 .

YEH, F.C., YANG, R.C. and BOYLE, T.,1999 [viewed 13 May 2014]. Population Genetics Software: POPGENE 32-version 1.31 [online]. Canada. Available from: http://www.ualberta. $\mathrm{ca} / \sim$ fyeh/fyeh

ZINS, K., MOGG, M., SCHNEEBERGER, C., ABRAHAM, D. and SCHREIBER, M., 2014. Analysis of the rs 10046 polymorphism of aromatase (CYP19) in premenopausal onset of human breast cancer. International Journal of Molecular Sciences, vol. 15, no. 1, pp. 712-724. http://dx.doi.org/10.3390/ijms15010712. PMid:24402127. 